\title{
PENERAPAN PENDEKATAN RECIPROCAL TEACHING UNTUK MENINGKATKAN MINAT BELAJAR SISWA DI ERA TEKNOLOGI
}

\author{
Risti Haerini' ${ }^{1}$, Gagan Aditya Fauzan², Martin Bernard ${ }^{3}$ \\ ${ }^{1,2,3}$ IKIP Siliwangi, Jln Terusan Jenderal Sudirman, Cimahi \\ 1dylla_riez@yahoo.com, ${ }^{2}$ kartika.djamin@gmail.com, ${ }^{3}$ muhammadafrilianto1@ikipsiliwangi.ac.id
}

\begin{abstract}
The purpose of this research is to increase students' interest in learning in the technological era by using the Reciprocal Teaching approach in learning. The method in this study is the experimental method, the research design is Posstest-only Control Design. Al Falah Banjaran High School is the school we chose to carry out research. With classes VII C and VII D as classes for research. Class VII C amounts to 25 students as the experimental class and class VII D amounts to 25 students as the control class. The instrument used in this study is a non-test instrument that is a student learning interest questionnaire that has been tested and declared valid and reliable. Data testing was performed using posttest data which was processed by the SPSS 20 application to conduct parametric statistical tests. The results showed that students' interest in learning using the Reciprocal Teaching approach was better than students whose learning used the usual approach.
\end{abstract}

Keywords: Reciprocal Teaching Approach, Interest in student learning, Era Technology.

\begin{abstract}
Abstrak
Tujuan dari Penelitian ini adalah untuk meningkatkan minat belajar siswa di era teknologi dengan menggunakan pendekatan Reciprocal Teaching dalam pembelajaran. Metode dalam penelitian ini yaitu metode eksperimen, desain penelitiannya adalah Posstest-only Control Design. SMPT Al Falah Banjaran adalah sekolah yang kami pilih untuk melaksanakan penelitian. Dengan kelas VII C dan VII D sebagai kelas untuk penelitian. Kelas VII C berjumlah 25 orang siswa sebagai kelas eksperimen dan kelas VII D berjumlah 25 siswa sebagai kelas kontrol. Instrumen yang digunakan dalam penelitian ini adalah instrumen non-tes yaitu angket minat belajar siswa yang telah diujicoba dan dinyatakan valid dan reliabel. Pengujian data dilakukan meggunakan data postes yang diolah aplikasi SPSS 20 untuk melakukan uji statistika parametrik. Hasil penelitian menunjukan bahwa minat belajar siswa dengan menggunakan pendekatan Reciprocal Teaching lebih baik daripada siswa yang pembelajarannya menggunakan pendekatan biasa.
\end{abstract}

Kata Kunci: Pendekatan Reciprocal Teaching, Minat Belajar Siswa, EraTeknologi.

How to cite: Haerini, R., Fauzan, GA., \& Bernard, M. (2019). Penerapan Model Pembelajaran Reciprocal Teaching untuk Meningkatkan Minat Belajar Siswa SMP di Era Teknologi. JPMI-Jurnal Pembelajaran Matematika Inovatif, X, 2 (5), 229-236.

\section{PENDAHULUAN}

Dewasa ini perkembangan dunia pendidikan dan teknologi meningkat dengan sangat pesat. Perkembangan teknologi dapat menunjang berbagai elemen dalam kehidupan global khususnya 
dalam dunia pendidikan. (Bernard, 2014) mengungkapkan bahwa teknologi harus didasari oleh ilmu pengetahuan maupun sebaliknya. Hal tersebut diperkuat dengan peraturan (Depdiknas, 2003)bahwa TIK bukan lagi merupakan mata pelajaran, melainkan TIK menjadi media pendukung dalam setiap mata pelajaran. Misalnya penggunaan aplikasi Microsoft PowerPoint yang biasanya digunakan guru dalam menampilkan materi-materi di depan kelas. Selain menimbulkan dampak positif teknologi juga membawa pengaruh negatif terhadap dunia pendidikan. Misalnya adalah maraknya game online seperti Mobile Legend, PUPG, Free Fire yang sangat berpengaruh terhadap minat belajar siswa terutama pada pelajaran Matematika. Rendahnya minat belajar matematika dapat dilihat pada hasil penelitian yang dilakukan oleh (Silviani, T.R, Jailani, Lusyana, E \& Hadi, 2017) kepada siswa kelas VII C SMP Negeri 12 Yogyakarta. Hasilnya adalah dari 34 siswa hanya 1 siswa saja yang minat belajarnya masuk pada kategori tinggi. Itu artinya hanya sedikit siswa yang mempunyai minat belajar dari banyaknya siswa. Hal ini juga ditemukan oleh peneliti di SMPT Al Falah Banjaran ketika melakukan pengamatan terhadap beberapa siswa ketika pelajaran kosong dimana ketika guru tidak mengisi waktu pembelajaran mereka bermain HP untuk game online bersama didalam kelas. Faktor lain yang mempengaruhi adalah peran guru. Dimana beberapa guru di SMP Pasundan Rongga masih cenderung paling aktif dalam pembelajaran sehingga siswa cenderung pasif dalam mengkomunikasikan pemahamannya pada kegiatan belajar mengajar.

Sekolah merupakan salah satu tempat terbaik untuk membentuk karakter siswa dan memberikan proteksi kokoh terhadap berbagai pengaruh negatif terhadap siswa. Menurut Ferari (Wulan, 2000) menyatakan bahwa belajar merupakan proses untuk mengubah prilaku siswa oleh faktor internal dan eksternal dalam kegiatan belajar mengajar. Faktor internal tersebut dapat berupa kecerdasan kognitif maupun afektif yang salah satunya adalah minat belajar yang dimiliki oleh siswa. Minat belajar merupakan salah satu hal yang sangat penting dan harus dimiliki oleh setiap siswa. Tanpa adanya minat belajar siswa akan cenderung susah memahami pembelajaran yang disampaikan oleh guru, terutama pelajaran matematika yang notabene merupakan salah satu pelajaran yang kurang diminati oleh siswa.

Hal ini dikarenakan menurut (Gie, 2004) minat merupakan hal penting untuk membuat seseorang tertarik, fokus, dan dapat mengabaikan gangguan eksternal pada saat memperhatikan suatu objek. Sehingga ketika seorang siswa memiliki minat belajar matematika yang baik maka siswa tersebut akan lebih mudah dalam menangkap apa yang disajikan oleh guru didepan kelas. Minat dan belajar memiliki kaitan yang erat, tanpa adanya minat siswa akan mudah bosan dan cenderung enggan mempelajari materi yang tersaji dalam buku pelajaran begitupun sebaliknya. Hal ini diperkuat dengan penelitian yang dilakukan oleh (Sirait, 2016)disalah satu SMP Negeri di Jakarta yang menunjukan bahwa minat belajar memiliki pengaruh positif terhadap prestasi belajar siswa. (Hendriana, H., Rohaeti, E., \& Sumarmo, 2017) memaparkan indikator-indikator minat belajar siswa antara lain sebagai berikut: (1) perasaan senang; (2) ketertarikan siswa; (3) keterlibatan siswa; (4) rajin dalam belajar dan rajin dalam mengerjakan tugas matematika; (5) tekun dan disiplin dalam belajar serta memiliki jadwal sendiri.

Bagi siswa yang aktif, maupun membentuk minat belajar bagi siswa yang pasif. Seorang guru dituntut untuk menguasai berbagai metode pembelajaran salah satunya adalah model pembelajaran Reciprocal Teaching. Menurut (Trianto, 2009) Reciprocal Teaching merupakan pendekatan/metode pembelajaran yang bersifat kontruktivisme yang memuat kegiatan merangkum, mengajukan pertanyaan, mengkonfirmasi dan memprediksi. Adapun langkahlangkah dalam pendekatan reciprocal teaching menurut Ann Brown (Argikas \& Khuzaini, 2016) anatara lain sebagai berikut: (1) menyimpulkan bahan ajar; (2) menyusun pertanyaan dan menyelesaikannya; (3) menjelaskan kembali pengetahuan yang diperolehnya; (4) kemudian 
memprediksikan pertanyaan selanjutnya dari persoalan yang disodorkan kepada siswa. Jadi dapat disimpulkan model pembelajaran Reciprocal Teaching adalah model pembelajaran yang membentuk peranan siswa aktif didalam kegiatan pembelajaran yang teriri dari kegiatan menyusun, menanya, menyimpulkan, dan memprediksi jawaban

Dengan berbagai pemaparan diatas maka penulis berinisiatif untuk melakukan penelitian disalah satu sekolah swasta di banjaran berupa penerapan model pembelajaran Reciprocal Teaching untuk meningkatkan minat belajar matematik siswa SMP guna untuk mengimbangi pengaruh negatif dari berkembangnya era teknologi modern

\section{METODE}

Metode Metode yang digunakan dalam penelitian ini adalah eksperimen. Populasinya adalah semua siswa SMP. Dalam penelitian terdiri dari dua kelompok yaitu kelas eksperimen dan kelas kontrol yang menjadi sampel dalam penelitan ini. Instrument dalam penelitian terdiri dari 20 pernyataan positif dan pernyataan negatif tentang minat belajar siswa. Jenis penelitian merupakan desain Posstest-only Control Design dimana peneliti hanya membandingkan hasil postes dari kelas eksperimen dan kelas kontrol (Sugiono, 2013). Adapun desain penelitiannya antara lain digambarkan sebagai berikut:

\section{$\begin{array}{lll}\mathbf{R} 1 & \mathbf{O}\end{array}$}

(Sugiono, 2013)

R2 0

\section{Keterangan:}

R1 : Kelas Ekperimen R2 : Kelas Kontrol

0 : Postes minat belajar

X : Pembelajaran dengan pendekatan Reciprocal Teaching

Adapun kualifikasi minat belajar menurut (Slameto, 2010) disajikan pada tabel 1 dibawah ini:

Tabel 1. Kualifikasi Minat Belajar

\begin{tabular}{ll}
\hline Interval Skor & Interpretasi \\
\hline $\mathbf{8 0}<\mathbf{M} \leq \mathbf{1 0 0}$ & Sangat Tinggi \\
$\mathbf{6 0}<\mathbf{M} \leq \mathbf{8 0}$ & Tinggi \\
$\mathbf{4 0}<\mathbf{M} \leq \mathbf{6 0}$ & Sedang \\
$\mathbf{2 0}<\mathbf{M} \leq \mathbf{4 0}$ & Rendah \\
$\mathbf{0}<\mathbf{M} \leq \mathbf{2 0}$ & Sangat Rendah \\
\hline
\end{tabular}

\section{HASIL DAN PEMBAHASAN}

\section{Hasil}

Berikut data hasil pengujian statistika parametrik data postes kedua kelas : 
Tabel 2 Uji Normalitas Data Postes Minat Belajar

\begin{tabular}{llll}
\hline Shapiro-Wilk & & & \\
\hline Kelas & Statistik & Df & Sig. \\
\hline Eksperimen & 0,97 & 25 & 0,56 \\
Kontrol & 0,96 & 25 & 0,52 \\
\hline
\end{tabular}

Didapat nilai signifikansi kelas eksperimen yaitu 0,56 dan nilai signifikansi kelas kontrol 0,52. Hal tersebut menunjukkan bahwa data pada kedua kelas berdistribusi normal, maka dilakukan uji homogenitas.

Tabel 3 Uji Homogenitas Data Postes Minat Belajar

\begin{tabular}{lll}
\hline & Levene Statistic & Signifikan \\
\hline Postes & 3,97 & 0,52 \\
\hline
\end{tabular}

Nilai signifikansi pada uji homogenitas adalah $0,52 \geq 0,05$ artinya varian data kedua kelompok kelas tersebut adalah homogen maka pengujian selanjutnya menggunakan uji t.

Tabel 4 Uji T-Test Data Postes Minat Belajar

\begin{tabular}{cccc}
\hline & \multicolumn{3}{c}{ Levene's Test for Equality of } \\
\cline { 2 - 3 } $\begin{array}{c}\text { Equal variances } \\
\text { assumed }\end{array}$ & $\mathrm{T}$ & $\mathrm{Df}$ & Sig. (2-tailed) \\
\cline { 2 - 3 } & & & 0,83 \\
0
\end{tabular}

Didapat nilai sig (2-tailed) yaitu 0,004. Dikarenakan dalam uji hipotesis satu pihak (1-tailed), maka nilai signifikansi $\quad 0,004=0,002,\left(\right.$ Jyant $\left._{44} 2009\right)$. Maka 60 ditolak artinya terdapat 2 perbedaan pencapaian skala minat belajar yang signifikan' antara kelas kedua kelas. Sedangkan untuk data deskriptif postes angket minat betajar pada ketas eksperimen dan kelas kontrol tersaji pada tabel 5 berikut:

\section{Pembahasan}

Penelitian ini dilakukan selama lima pertemuan yang mencangkup pada pertemuan pertama sampai dengan pertemuan empat untuk pembelajaran dengan menggunakan pendekatan reciprocal teaching pada kelas eksperimen, dan pertemuan lima diadakan postes. Adapun tahapan atau langkah-langkah pendekatan reciprocal teaching pada kelas eksperimen yaitu sebagai berikut: (1) menyimpulkan bahan ajar; (2) menyusun pertanyaan dan menyelesaikannya; (3) menjelaskan kembali pengetahuan yang diperolehnya;

(4) kemudian memprediksikan pertanyaan selanjutnya dari persoalan yang disodorkan kepada siswa.

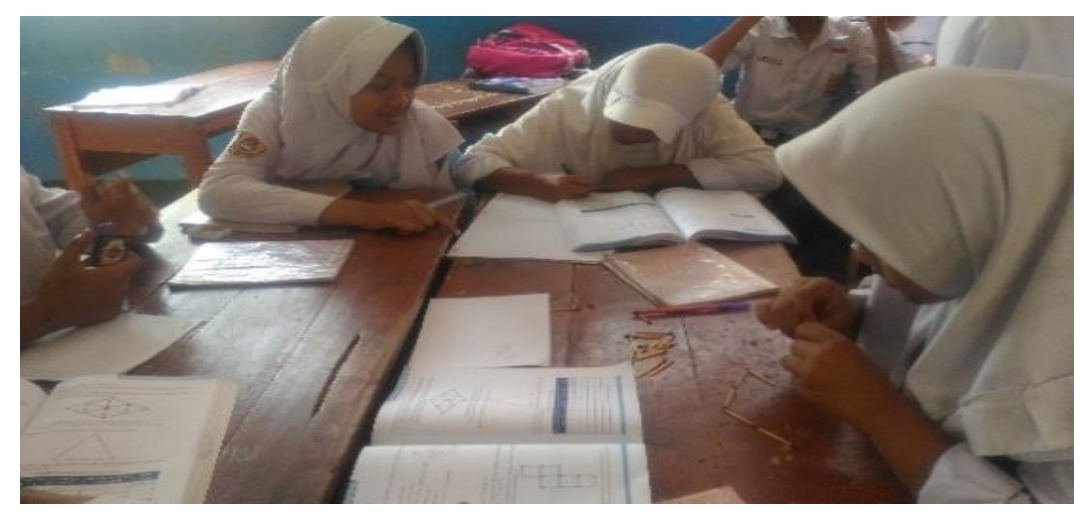

Gambar 1. Menyimpulkan Bahan Ajar dan Menyusun Pertanyaan 
Guru memberikan Lembar Kerja Siswa (LKS) setelah memberikan informasi dan tujuan pembelajaran. Guru membimbing setiap kelompok dan memberi arahan kepada siswa supaya membuat pertanyaan sesuai yang diharapkan. Guru memberikan kesempatan kepada siswa untuk menyimpulkan bahan ajar di depan kelas, setelah semua menyimpulkan bahan ajar siswa di arahkan untuk membuat soal dan menyelesaikannya bersama teman kelompoknya

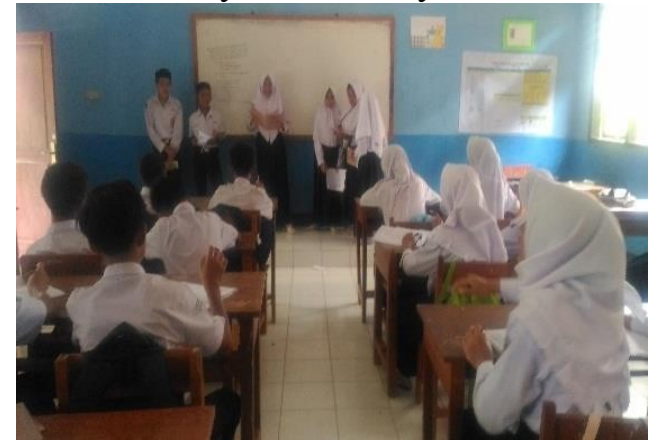

Gambar 2 .Siswa Mempresentasikan Hasil Kerja Kelompok

Guru memberikan kesempatan kepada siswa untuk mempresentasikan hasil kerja kelompoknya. Hanya perwakilan 1 kelompok saja yang memperesentasikan di depan kelas. Guru mempersilahkan kelompok lain memberikan tangkapan maupun masukan jika jawaban dari yang dipresentasikan oleh kelompok presenter kurang tepat.

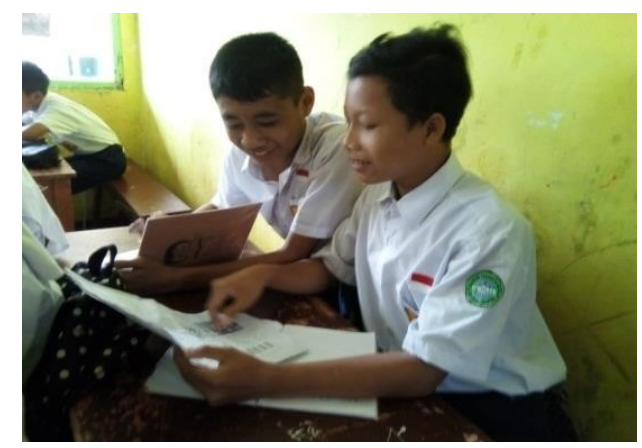

Gambar 3. Siswa memprediksi Soal yang Akan Muncul

Setelah itu siswa di ajak untuk memprediksi soal yang akan muncul pada pembelajaran selanjutnya agar siswa terlatih untuk mengerjakan soal yang lebih sulit dari sebelumnya. Pada pertemuan akhir pembelajaran yaitu pada pertemuan ke lima dilaksanakannya tes akhir atau postes untuk mengetahui adanya perbedaan minat belajar matematik siswa setelah mendapat pembelajaran dengan menggunakan pendekatan reciprocal teaching. Langkah- langkah pembelajaran diatas sesuai dengan apa yang diungkapkan oleh Ann Brown (Argikas \& Khuzaini, 2016) mengenai model pembelajaran reciprocal teaching.

Setelah implementasi selanjutnya akan dibahas mengenai indikator-indikator minat belajar yang memiliki perbedaan signifikan antara kelas eksperimen dengan kelas kontrol. Berikut akan dibahas per indikator minat belajar siswa antara lain: Perasaan senang dan ketertarikan siswa. siswa yang memiliki perasaan yang senang akan menunjukan ketertarikannya terhadap pembelajaran matematika. Hal ini sejalan dengan Teori Gestalt (Fauzan, GA., Aripin, 2018) menyatakan bahwa belajar tidak mungkin tanpa keinginan belajar, maka kesukaan siswa terhadap sikap yang dilahirkan guru jelas akan memberikan motivasi tersendiri dalam belajar. Dengan perasaan senang siswa akan lebih mudah menyerap pembelajaran yang dilaukan didalam kelas. Hal ini sejalan dengan pendapat (Fauzan, GA., Aripin, 2018) bahwa siswa yang merasa senang dalam kegiatan pembelajaran dia akan mulai menyukai guru dan pembelajaran 
yang sedang dia lakukan. Selain itu, melakukan penemuan berupa antusiasme siswa dalam kegiatan belajar mengajar. Berikut adalah gambar yang menunjukan antusiasme siswa dalam kegiatan pembelajaran dimana siswa melakukan suit untuk menjawab pertanyaan kuis yang diajukan oleh guru tersaji pada gambar 3 berikut:

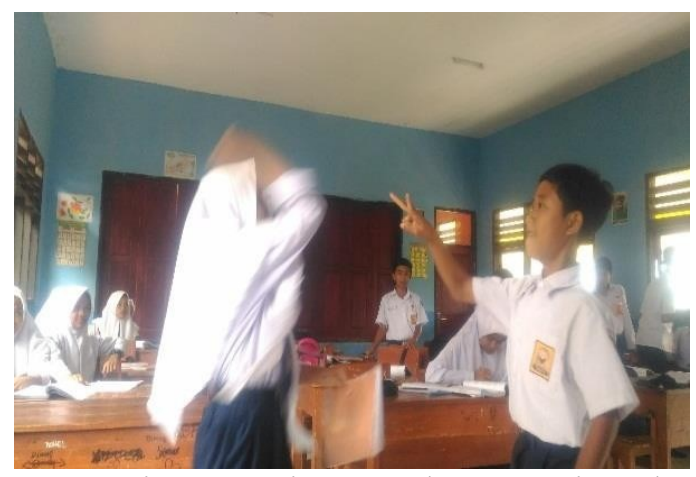

Gambar 4. Antusisasme Siswa Dalam Menjawab Pertanyaan

Rajin dalam belajar dan rajin dalam mengerjakan tugas matematika. Berdasarkan pengamatan yang dilakukan oleh penulis, terlihat bahwa siswa jadi cenderung rajin mengerjakan soal-soal yang diberikan oleh guru. Bahkan beberapa siswa menanyakan soal-soal yang belum pelajarari sebelumnya. Hal ini dikarenakan model pembelajaran reciprocal teaching melatih siswa untuk aktif dan mandiri dalam mengatasi permasalahan-permasalahan yang ditemukan dalam soal. Sehingga siswa jadi terpacu dan termotivasi untuk mengerjakan tantangan-tantangan baru yang ditemukan dalam soal yang baru. Berikut adalah potret siswa yang menunjukan minat belajar pada indikator rajin dalam belajar dan mengerjakan tugas matematika:

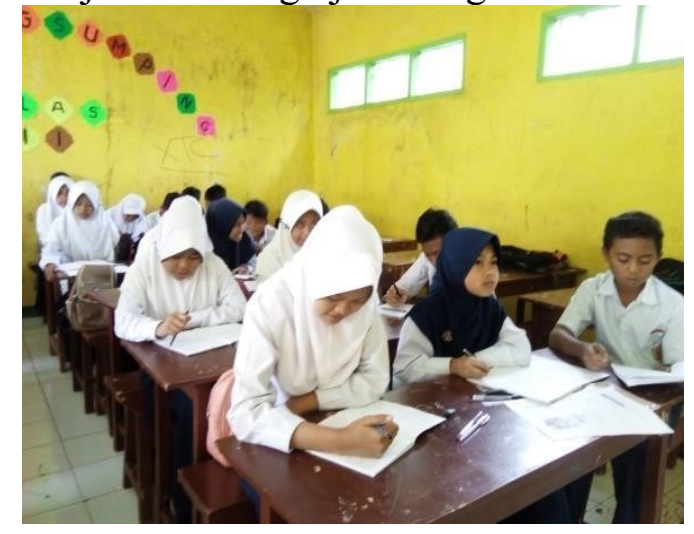

Gambar 5. Rajin Dalam Mengerjakan Tugas Matematika

Tekun dan disiplin. Pada indikator ini penulis melakukan pengamatan baik dalam pembelajaran maupun diluar jam pembelajaran dimana siswa menajdi rajin membahas beberapa soal baik pelajaran matematika maupun pelajaran lainnya didalam kelas. Tidak bermain game online. Berdasarkan pengamatan yang dilakukan oleh penulis, terlihat siswa tidak lagi terlihat bermain game online bersama lagi didalam kelas.

\section{KESIMPULAN}

Berdasarkan data hasil dan uraian diatas dapat disimpulkan bahwa penerapan model pembelajaran reciprocal teaching dalam pembelajaran matematika SMP kelas VII di SMPT Al 
Falah dapat meningkatkan minat belajar matematik siswa. Kesimpulan tersebut didapat dengan melakukan uji statistika parametrik yang menunjukan adanya perbedaan yang signifikan dimana kelas yang menggunakan yang pembelajarannya menggunakan model pembelajaran reciprocal teaching lebih baik daripada kelas yang pembelajarannya tanpa menggunakan model pembelajaran biasa. Minat belajar matematik siswa juga ditunjukkan berdasarkan pengamatan bahwa siswa menjadi lebih semangat dalam melakukan kegiatan pembelajaran matematik dan mulai mengurangi kebiasaan bermain game online bersama didalam kelas

\section{DAFTAR PUSTAKA}

Argikas, T. B., \& Khuzaini, N. (2016). Penerapan model pembelajaran Reciprocal Teaching untuk meningkatkan pemahaman konsep matematika siswa kelas VII SMP negeri 2 depok. Jurnal Mercumatika, 1(1)(1), 67-79.

Bernard, M. (2014). Meningkatkan Kemampuan Penalaran Matematik Siswa SMA Melalui Game Adobe Flash CS 4. InInProsiding Seminar Nasional Pendidikan Matematika, 3, 205-213.

Depdiknas. (2003). Kumpulan Pedoman Kurikulum 2004.

Fauzan, GA., Aripin, U. (2018). Penerapan Ice Breaking dalam Pembelajaran Matematika untuk Meningkatkan Rasa Percaya Diri Siswa Kelas VIII B SMP Bina Harapan Bangsa. Jurnal Pembelajaran Matematika Inovatif.

Gie, T. L. (2004). Cara Belajar yang Baik Bagi Mahasiswa.

Hendriana, H., Rohaeti, E., \& Sumarmo, U. (2017). Soft Skill dan Hard Skill Matematik Siswa.

Silviani, T.R, Jailani, Lusyana, E \& Hadi, A. . (2017). Upaya Meningkatkan Minat Belajar Matematika Menggunakan Inquiry Based Learning Setting Group Investigation. Jurnal Matematika Kreatif-Inovatif.

Sirait, E. D. (2016). 750-2124-1-Pb. 6(1), 35-43.

Slameto. (2010). Belajar dan Faktor-faktornya yang Mempengaruhi.

Sugiono. (2013). Metode Penelitian Pendidikan Pendekatan Kuantitatif, Kualitatif, dan R \& D.

Trianto. (2009). Model-model Pembelajaran Inovatif Berorientasi Konstruktistik.

Uyanto. (2009). Pedoman Analisis Data dengan SPSS.

Wulan, R. (2000). Hubungan Antara Pengasuhan Orangtua Dengan Prokrastinasi Akademik Pada Remaja SMU. 
236 Haerani, Fauzan \& Bernard, Penerapan Model Pembelajaran Reciprocal Teaching .... 